\title{
Comparative Effects of the Application of Prilled Urea and Urea Supergranules on Flooded Rice in Madagascar
}

\author{
Guido D’Onofrio \\ Project leader of FAO fertilizer programme; c/o FAO, Antananarivo, Madagascar \\ Present address: via San Matteo 45, San Gimignano (SI), Italy \\ Tel: +39-349- 6944436 E-mail: guido_donofrio@yahoo.com
}

Jacques Dupuy \& Rémi Gaudin

Laboratoire des Radioisotopes, BP 3383, Antananarivo 101, Madagascar

Present address: SupAgro, UMR System, 2 place Viala, 34060 Montpellier, France

Tel: 33-4-99-61-20-59 E-mail: remi.gaudin@ supagro.fr

Received: January 10, 2018

doi:10.5296/jas.v6i1.12741
Accepted: January 26, 2018

URL: https://doi.org/10.5296/jas.v6i1.12741

\begin{abstract}
Applying urea supergranules to flooded rice (10 cm deep, 3 weeks after transplantation) is associated with yield increases of 17\%, 23\%, 22\% and 16\% (for doses of 27, 54, 81 and 108 units of nitrogen per hectare) compared with prilled urea. Nitrogen-15 can be used to establish the real nitrogen utilization coefficients for the aerial parts of the plant. While the figures are very low for prilled urea (between $4 \%$ and 9\%), they exceed $25 \%$ and $38 \%$ for supergranules on the sites studied. The effect of fertilizer form is greater than the dosage factor. The results are discussed in terms of apparent utilization coefficients and mechanism used.
\end{abstract}

Keywords: Urea, Oryza sativa L., deep placement

\section{Introduction}

In Madagascar, increasing rice production is largely dependent on the level of nitrogen fertilizer, as low tillering in rice fields on the central high plateau is mainly due to nitrogen deficiency. Imported fertilizers have a particularly high cost price owing to the distance from producer countries, as well as transportation difficulties on the island itself. Improving the effectiveness of fertilizers is a priority objective. 
Many solutions have been put forward to limit nitrogen losses. The simplest suggestions consist in splitting up the inputs. More effective proposals use composite processing to produce a gradual release of nitrogen into the soil (Sharma and Prasad, 1980). Lastly, some use nitrification inhibitors with nitrogen fertilizers. However, the positive results may be offset by increased production costs (Chien et al., 2009). Some of the most affordable methods include urea mixed with various substances in the form of balls (neem cake or mud balls) or simply granules (USG, urea supergranules) weighing between $1 \mathrm{~g}$ and $3 \mathrm{~g}$ (Savant and Stangel, 1990; Bandaogo et al., 2015). The efficiency of the various formats can be strengthened by the means and date of application.

Several tests were carried out to compare the effect of the prilled urea and the USGs and to establish the nitrogen utilization coefficients for the aerial parts of flooded rice in two experiments involving Nitrogen-15. These tests were carried out in collaboration with the International Atomic Energy Agency (IAEA).

\section{Equipment and Method}

Although seven tests (including two with Nitrogen-15) were carried out on various sites flooding and disease caused two tests to be lost. The remainder were distributed as follows:

- MAHITSY ${ }^{1}$ (research station) - Hydromorphic soil with pseudogley topsoil

- ARIVONIMAMO² (farmer) - Hydromorphic mineral soil with pseudogley topsoil

- FIANARANTSOA (farmer) - Hydromorphic soil with gley topsoil

- ALAOTRA (research station) - Hydromorphic alluvial deposit with pseudogley

- AMBATONDRAZAKA (research station) - Alluvial-lacustrine peat

The test pattern was a randomized bloc of 14 treatments (with the main ones being USGs and prilled urea) with 4 replications to give 56 plots of $10 \mathrm{~m}^{2}$ (10 five-metre lines). Irrigation and drainage were en bloc. The rice variety used was 1632 (chianan 8) transplanted at the two-strand stage, $20 \mathrm{~cm}$ apart with plants 30 to 40 days old.

Next to a full control, the other plots received a basal dressing of 90 units of $\mathrm{P}_{2} \mathrm{O}_{5}$ (super-triple) and 90 units of $\mathrm{K}_{2} \mathrm{O}(\mathrm{KCl})$ applied after levelling. The nitrogen doses were 0-27-54-81-108 units per ha. The size of the USGs was 1-2-3 grams, and they were buried with a stick at a depth of $8-10 \mathrm{~cm}$. They were set out as follows:

27 units per ha $=1$ USG of $1 \mathrm{~g}$ for 4 clumps

54 units per ha $=1 \mathrm{USG}$ of $1 \mathrm{~g}$ for 2 clumps $=1 \mathrm{USG}$ of $2 \mathrm{~g}$ for 4 clumps $=2$ USGs of $1 \mathrm{~g}$ for 4 clumps

81 units per ha $=1$ USG of $3 \mathrm{~g}$ for 4 clumps

108 units per ha $=1 \mathrm{USG}$ of $1 \mathrm{~g}$ for $1 \mathrm{clump}=1 \mathrm{USG}$ of $2 \mathrm{~g}$ for 2 clumps

\footnotetext{
1 Nitrogen-15.

${ }^{2}$ Nitrogen-15.
} 


\section{Macrothink}

Journal of Agricultural Studies

ISSN 2166-0379

2018, Vol. 6, No. 1

The prilled urea was placed at the bottom of a furrow of the same depth. Nitrogen inputs were added when the plants took root three weeks after transplantation.

Nitrogen-15, with its isotopic content of more than 1\%, was applied to a surface area of 0.96 $\mathrm{m}^{2}$ ( 2 lines of 5 plants) in two of the tests: Arivonimamo and Mahitsy. For the dose of 54 nitrogen units per ha, the $1 \mathrm{~g}$ USGs were inserted either as one granule per two clumps $\left(54 \mathrm{G}_{1}\right)$ or two granules for four clumps $4\left(54 \mathrm{G}_{2}\right)$. The marked USGs were produced by double wrapping enriched urea firmly in tissue paper.

Once harvested and machined-dried, the subsampled straws and grains were mixed and then nitrogen was determined following Kjeldahl mineralization and steam distillation. The doses of nitrogen and the isotope surplus were measured by IAEA using mass spectrometry because the optic spectrometer available at Antananarivo University cannot determine the low isotopic excess of the plant samples.

\section{Results and Discussion}

\subsection{All tests}

The curves (Figure 1) show a good response to nitrogen with a marked effect for the form of fertilizer. The USGs showed a greater effectiveness than prilled urea, with the difference between the methods particularly pronounced for average doses.

For doses of 54 units and 81 units, respectively, the percentage increases were $64 \%$ for prills and $102 \%$ for USGs with the former dose, and $81 \%$ for prills and $122 \%$ for USGs with the latter dose (Table 1).

The placement and size of granules did not seem to have much bearing on the results obtained. 


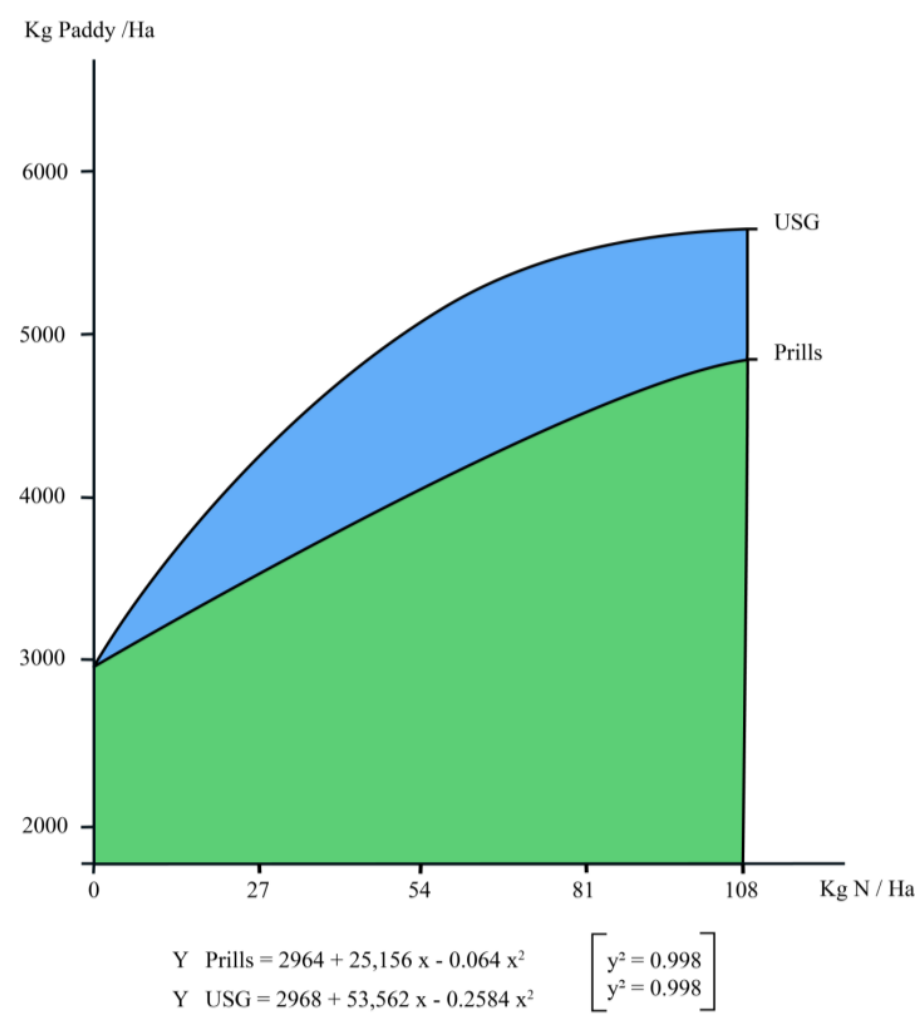

Figure 1. Response curve of rice yield to prilled urea and deep-placed USGs. Mean of 5 trials

Table 1. Mean yield per treatment (all tests harvested)

\begin{tabular}{|c|c|c|c|}
\hline $\begin{array}{c}\text { Treatments N-P-K } \\
\text { (units/ha) }\end{array}$ & $\begin{array}{c}\text { Yield } \\
(\mathrm{kg} / \mathrm{ha})\end{array}$ & $\begin{array}{c}\text { Yield Increase } \\
(\mathrm{kg} / \mathrm{ha})\end{array}$ & $\begin{array}{c}\text { Yield Increase } \\
(\%)\end{array}$ \\
\hline $0-0-0$ & 2526 & - & - \\
$0-90-90$ & 2963 & 437 & 17 \\
\hline $27-90-90$ (Prills) & 3596 & 1070 & 42 \\
$27-90-90$ (USG) & 4226 & 1700 & 67 \\
\hline $54-90-90$ (Prills) & 4135 & 1609 & 64 \\
$54-90-90$ (USG) & 5107 & 2581 & 102 \\
\hline $81-90-90$ (Prills) & 4581 & 2055 & 81 \\
$81-90-90$ (USG) & 5612 & 3086 & 122 \\
\hline
\end{tabular}




\begin{tabular}{|c|c|c|c|}
\hline $108-90-90$ (Prills) & 4934 & 2408 & 95 \\
$108-90-90$ (USG) & 5740 & 3215 & 127 \\
\hline
\end{tabular}

\subsection{Nitrogen-15 tests}

\subsubsection{Overall results}

\section{Dosage factor}

For all of the parameters measured, the deviations between prilled urea receiving 54 and 81 units of nitrogen per ha were very small and not significant. They were slightly larger and at times significant for the USGs (Table 2 and Figures 2, 3, 4 and 5).

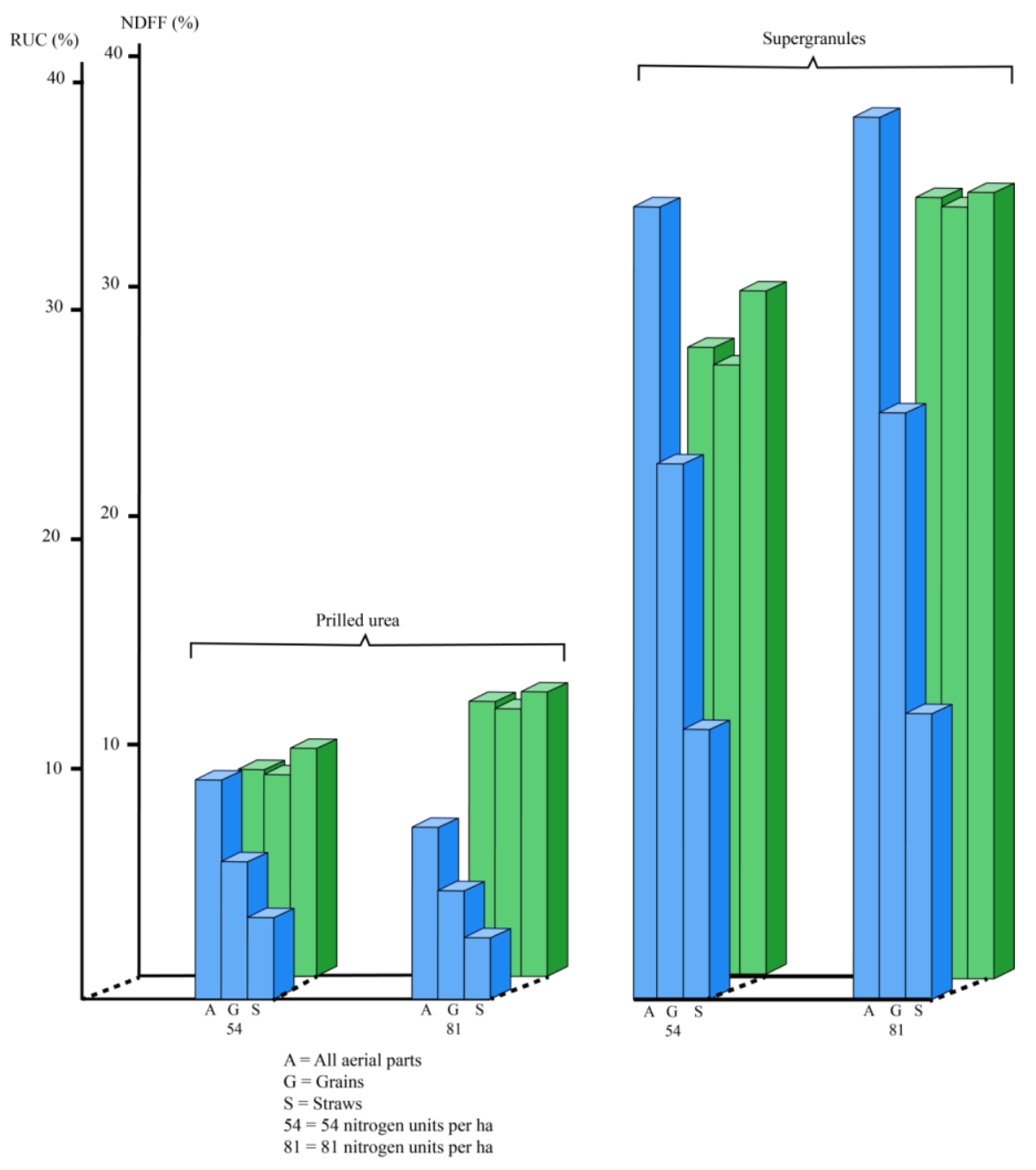

Real Utilization Coefficient (RUC $\square$ )

Nitrogen Derived From Fertilizer (NDFF

Figure 2. Real Utilization Coefficient (RUC) and Nitrogen Derived From Fertilizer (NDFF) in the Arivonimamo test. 
Table $2 .{ }^{15} \mathrm{~N}$ test results for Arivonimamo and Mahitsy

Arivonimamo

\begin{tabular}{|c|c|c|c|c|}
\hline Treatment & $\begin{array}{l}\text { Part of the } \\
\text { plant }\end{array}$ & $\begin{array}{l}\text { Harvest } \\
\text { weight } \\
\left(\mathrm{kg} \cdot \mathrm{ha}^{-1}\right)\end{array}$ & $\begin{array}{l}\text { Proportion of } \\
\text { nitrogen }(\%)\end{array}$ & $\begin{array}{c}\text { Isotopic excess } \\
\text { E }(\%)\end{array}$ \\
\hline \multirow{3}{*}{$\begin{array}{c}54 \mathrm{U} \\
\left(\begin{array}{l}54 \mathrm{~kg} \mathrm{~N} \text { in prills } \\
\text { per ha })\end{array}\right.\end{array}$} & Straw & 4007 & 0.52 & 0.101 \\
\hline & Grain & 4341 & 0.92 & 0.088 \\
\hline & Aerial & 8349 & 0.72 & 0.091 \\
\hline \multirow{3}{*}{$\begin{array}{c}81 \mathrm{U} \\
(81 \mathrm{~kg} \mathrm{~N} \text { in prills } \\
\text { per ha })\end{array}$} & Straw & 3953 & 0.49 & 0.125 \\
\hline & Grain & 4001 & 0.90 & 0.118 \\
\hline & Aerial & 7954 & 0.70 & 0.121 \\
\hline \multirow{3}{*}{$\begin{array}{c}54 \mathrm{G} 1 \\
(54 \mathrm{~kg} \mathrm{~N} \text { in USGs } \\
\text { per ha) }\end{array}$} & Straw & 5281 & 0.47 & 0.309 \\
\hline & Grain & 6271 & 0.84 & 0.258 \\
\hline & Aerial & 11552 & 0.67 & 0.275 \\
\hline \multirow{3}{*}{$\begin{array}{c}54 \mathrm{G} 2 \\
(54 \mathrm{~kg} \mathrm{~N} \text { in USGs } \\
\text { per ha) }\end{array}$} & Straw & 4552 & 0.48 & 0.289 \\
\hline & Grain & 6029 & 0.84 & 0.277 \\
\hline & Aerial & 10581 & 0.68 & 0.280 \\
\hline \multirow{3}{*}{$\begin{array}{c}81 \mathrm{G} \\
(81 \mathrm{~kg} \mathrm{~N} \text { in USGs } \\
\text { per ha) }\end{array}$} & Straw & 6406 & 0.51 & 0.342 \\
\hline & Grain & 7134 & 0.95 & 0.337 \\
\hline & Aerial & 13540 & 0.75 & 0.339 \\
\hline
\end{tabular}


Mahitsy

\begin{tabular}{|c|c|c|c|c|}
\hline Treatment & Part of the plant & $\begin{array}{c}\text { Harvest weight } \\
\qquad\left(\mathrm{kg} \cdot \mathrm{ha}^{-1}\right)\end{array}$ & $\begin{array}{l}\text { Proportion of } \\
\text { nitrogen }(\%)\end{array}$ & $\begin{array}{c}\text { Isotopic excess } \\
\text { E }(\%)\end{array}$ \\
\hline \multirow{3}{*}{$\begin{array}{c}54 \mathrm{U} \\
(54 \mathrm{~kg} \mathrm{~N} \text { in } \\
\text { prills per ha) }\end{array}$} & Straw & 4040 & 0.58 & 0.05 \\
\hline & Grain & 2584 & 1.17 & 0.04 \\
\hline & Aerial & 6624 & 0.82 & 0.044 \\
\hline \multirow{3}{*}{$\begin{array}{c}81 \mathrm{U} \\
(81 \mathrm{~kg} \mathrm{~N} \text { in } \\
\text { prills per ha) }\end{array}$} & Straw & 4040 & 0.58 & 0.068 \\
\hline & Grain & 2630 & 1.24 & 0.068 \\
\hline & Aerial & 6670 & 0.84 & 0.068 \\
\hline \multirow{3}{*}{$\begin{array}{c}54 \mathrm{G} 1 \\
(54 \mathrm{~kg} \mathrm{~N} \text { in } \\
\text { USGs per ha) }\end{array}$} & Straw & 4040 & 0.68 & 0.211 \\
\hline & Grain & 3437 & 1.24 & 0.176 \\
\hline & Aerial & 7477 & 0.94 & 0.188 \\
\hline \multirow{3}{*}{$\begin{array}{c}54 \mathrm{G} 2 \\
(54 \mathrm{~kg} \mathrm{~N} \text { in } \\
\text { USGs per ha) }\end{array}$} & Straw & 4299 & 0.76 & 0.212 \\
\hline & Grain & 2948 & 1.25 & 0.203 \\
\hline & Aerial & 7247 & 0.96 & 0.206 \\
\hline \multirow{3}{*}{$\begin{array}{c}81 \mathrm{G} \\
(81 \mathrm{~kg} \mathrm{~N} \text { in } \\
\text { USGs per ha) }\end{array}$} & Straw & 4560 & 0.85 & 0.295 \\
\hline & Grain & 3112 & 1.37 & 0.273 \\
\hline & Aerial & 7672 & 1.06 & 0.282 \\
\hline
\end{tabular}

\section{Form factor}

Assessed in terms of relative deviations: $R D=(G-U) / U$ with $G$ and $U$ for USGs and prills.

The main effects were as follows:

Yield: improved effectiveness of USGs gave rise to relative deviations of $20 \%$ for straws and $40 \%$ for grains.

Nitrogen export: the pattern here was similar, albeit with straw results being closer to those for grains.

Nitrogen derived from fertilizer (NDFF): the ratio between the isotopic surplus of the plant and the fertilizer is often quoted in the literature, and varies little according to the part of the 


\section{Macrothink}

Journal of Agricultural Studies

ISSN 2166-0379 2018, Vol. 6, No. 1

plant. However, the relative deviations between USGs and prilled urea were above $200 \%$. While the fertilizer rate remained constant for dosage or plant part, the fertilizer availability was increased when the nitrogen is placed at depth.

Real utilization coefficients (RUC): there were large relative deviations in nitrogen RUCs for straws and grains alike. The placement of USGs resulted in better utilization of the fertilizer than for the prilled urea. However, there were significant differences between the two test points for each treatment and between treatments for most parameters analysed (Figures 2 and 3).
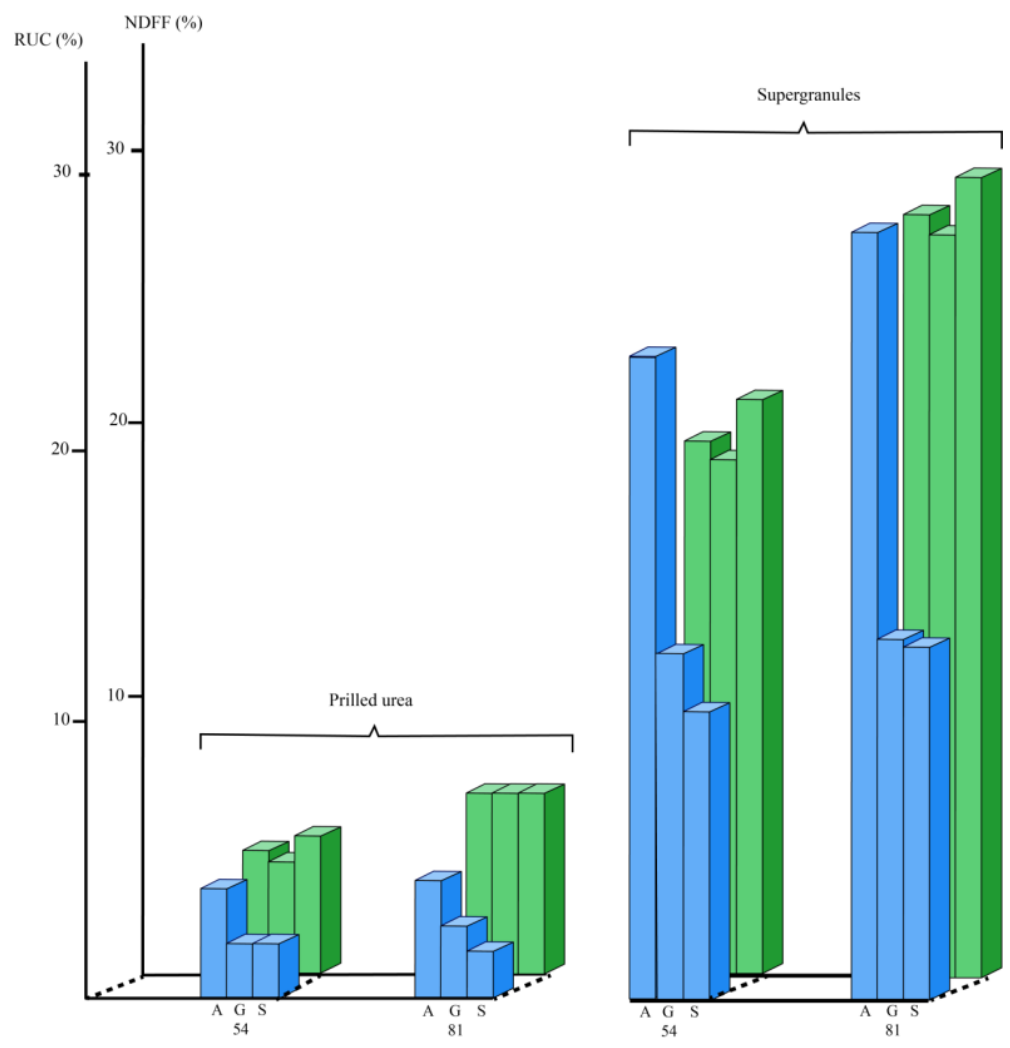

A $=$ All aerial part

$\mathrm{G}=$ Grains
$\mathrm{S}=$ Straws

$54=54$ nitrogen units per ha

$81=81$ nitrogen units per $\mathrm{h}$

Real Utilization Coefficient (RUC $\square$ )

Nitrogen Derived From Fertilizer (NDFF $\square$ )

Figure 3. Real Utilization Coefficient (RUC) and Nitrogen Derived From Fertilizer (NDFF) in the Mahitsy test. 


\section{Macrothink}

3.2.2 Comparison of results between treatments and between sites

\section{Yields (Table 2)}

With the prilled urea treatments, the straw weights were similar in Mahitsy and Arivonimamo.

The USGs treatment, however, was associated with a very significant increase in straw harvested in Arivonimamo (relative deviation of 36\%) and a slight increase in Mahitsy (6\%). For grain weights, the deviations widened for prills but mainly for USGs. Relative deviations were just $21 \%$ in Mahitsy but over 55\% in Arivonimamo. The improved effectiveness of the USG treatment observed for straws was mostly confirmed for grains also.

Plant growth, which was weaker in Mahitsy than in Arivonimamo, was improved by placing the fertilizer at depth. However, this effect tended to accentuate the deviations between the sites.

Nitrogen taken by the rice crop (Figures 4 and 5)

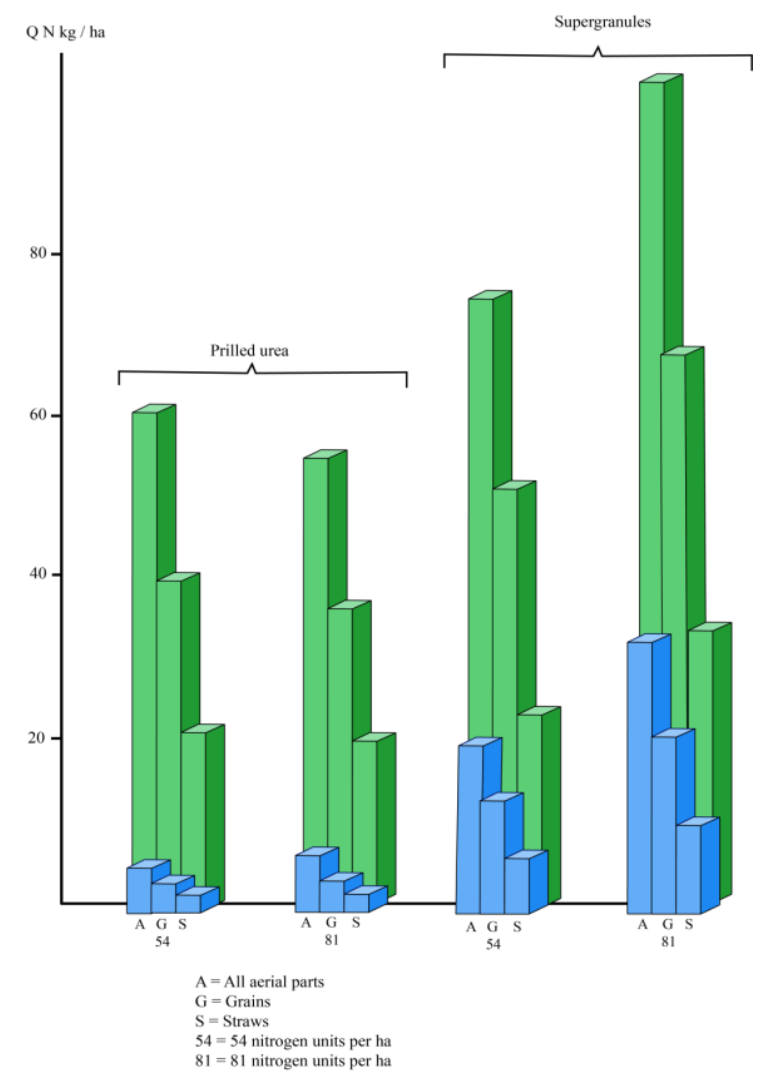

Figure 4. Total quantity of nitrogen exported (in green) and quantity of nitrogen from fertilizer (in blue) in Arivonimamo test. 


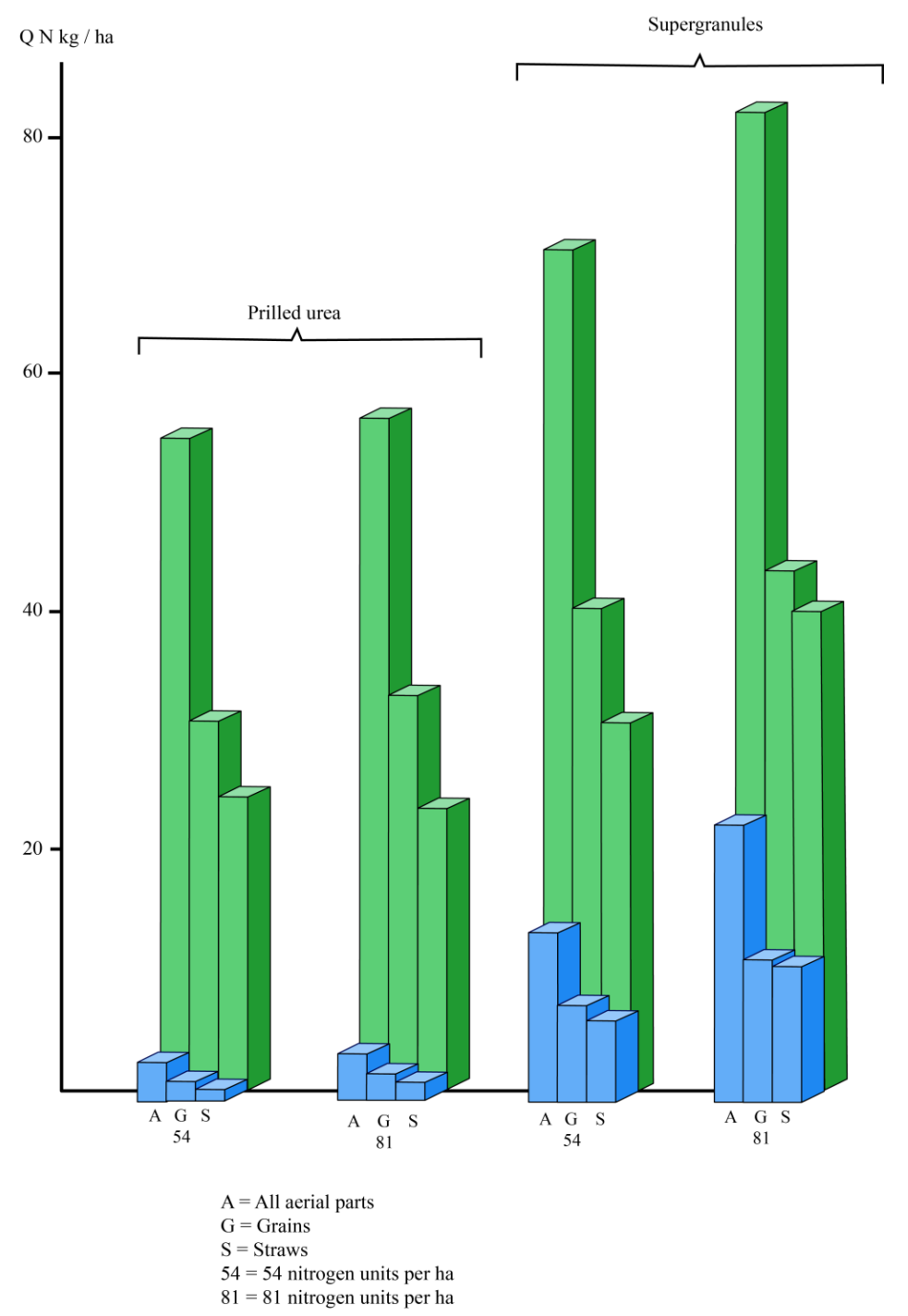

Total quantity of nitrogen exported ( $\square)$

Quantity of nitrogen from fertilizer ( $\square$ )

Figure 5. Total quantity of nitrogen exported and quantity of nitrogen from fertilizer in Mahitsy test.

As nitrogen levels were higher in Mahitsy than in Arivonimamo, the deviations in the nitrogen export quantities were smaller than the weight variations (regardless of the form of fertilizer used). The amount of nitrogen in straws was slightly higher in Mahitsy than in Arivonimamo, despite observations carried out for dry weights. The relative deviations between treatments are similar in Arivonimamo (33\%) and Mahitsy (39\%). 


\section{Al Macrothink}

Journal of Agricultural Studies

ISSN 2166-0379

2018, Vol. 6, No. 1

The higher nitrogen export in Mahitsy than in Arivonimamo was not replicated for grains, which showed similar patterns to those recorded for yield.

The relative deviation for supergranules was $51 \%$ in Arivonimamo (55\% for dry weight) and $33 \%$ in Mahitsy (36\% for weight).

In terms of total nitrogen exports, the deviations between Mahitsy and Arivonimamo were smaller than for yields (due to the improved performance of straws in Mahitsy).

Overall, growth in Mahitsy would remain weak or weaken further compared with Arivonimamo throughout the cycle.

NDFF (Figures 2 and 3)

While the NDFF for straws and grains were similar as stated earlier, it did vary according to the treatment and site in question.

The figures for prilled urea were almost twice as high in Arivonimamo (10.6\%) as in Mahitsy (5.6\%). Although the figures were much higher for the USG treatments $(29.8 \%$ and $22.6 \%$, respectively), the scale of the deviations increased only slightly. As a result, the relative deviation due to USGs was stronger in Mahitsy (300\%) than in Arivonimamo (180\%).

RUCs (Figures 2 and 3)

Irrespective of treatment, the larger nitrogen exports by straws did not offset the weaker nitrogen intervention rates (with lower RUCs in Mahitsy).

As for grains, as nitrogen exports and NDFF were lower in Mahitsy than in Arivonimamo, the deviations between RUCs are wider.

For USGs, grain RUCs did not reach $14 \%$ in Mahitsy but exceeded 25\% in Arivonimamo. However, the relative variations were larger in Mahitsy (450\%) than in Arivonimamo $(350 \%)$.

Based on lower performance, strictly speaking the USGs effect was greater in Mahitsy than in Arivonimamo.

AUCs (Figure 6)

For grains, apparent utilization coefficients (AUCs) (based on the deviation between the nitrogen exported and the nitrogen-free treatment for the amount of fertilizer nitrogen) gave rise to the following observations:

They were higher in Arivonimamo than in Mahitsy, regardless of treatment and dosage

They were higher for USG treatments than for prilled urea

The dosage effect was only clearly significant for prilled urea in Arivonimamo, as the AUCs for 54 nitrogen units per hectare were greater than for 81 units

They were always higher than the RUCs and this led to an overestimation of the participation of fertilizer. This must be due to a stimulation effect of the plant withdrawing 
the nitrogen from the soil caused by the fertilizer.

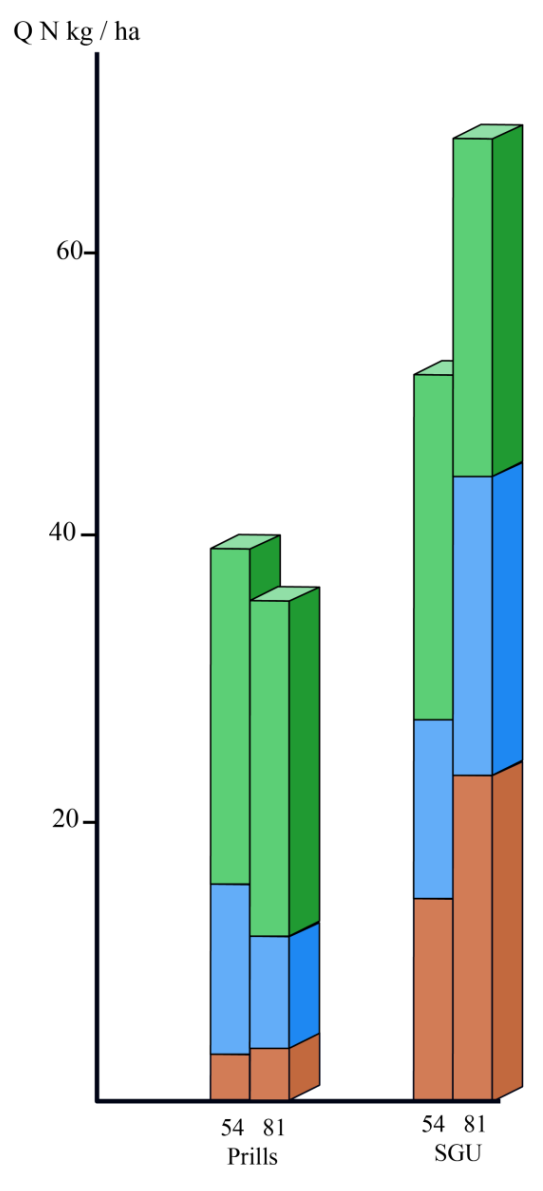

ARIVONIMAMO

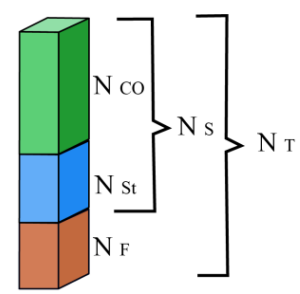

$\mathrm{Ns}_{\mathrm{S}}=\mathrm{N}_{\mathrm{T}}-\mathrm{N}_{\mathrm{F}}$

$\mathrm{NSt}_{\text {St }}=\mathrm{NCO}_{\mathrm{CO}} \mathrm{N}_{\mathrm{F}}$

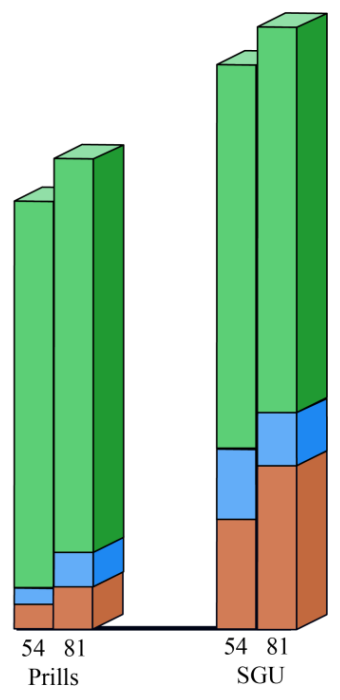

MAHITSY

$\mathrm{N}$ CO $=$ Nitrogen exported by control

$\mathrm{N}_{\mathrm{T}}=$ Nitrogen exported by test

$\mathrm{N}_{\mathrm{F}}=$ Nitrogen from fertilizer

$\mathrm{N} \mathrm{St}=$ Stimulation effect from nitrogen in soil

Figure 6. Nitrogen exported by grain.

The deviation between the apparent quantities and real quantities of nitrogen from fertilizer made it possible to quantify the stimulation effect.

In Arivonimamo, they were 12.1 to 7.8 for prilled urea and 13.6 and $21.4 \mathrm{~kg}$ of nitrogen per hectare for USGs at doses of 54 and 81 units.

The smaller differences in Mahitsy were 1.6 to $4.3 \mathrm{~kg}$ for prilled urea and 5 to $3.5 \mathrm{~kg}$ of nitrogen per hectare for USGs

In Arivonimamo, nitrogen export due to the stimulation effect was over twice as large as the nitrogen uptake from fertilizer for prilled urea, whereas the magnitude is similar for USGs. 
The situation was different in Mahitsy because the prilled urea underwent a similar stimulation effect as for fertilizer nitrogen uptake. The phenomenon was reversed for USGs (with nitrogen from fertilizer being more significant than the increased nitrogen uptake due to the stimulation effect).

\subsection{Elements to establish the most appropriate practices}

The maximum yield was achieved by $196 \mathrm{~kg}$ per hectare of prills, but just $104 \mathrm{~kg}$ per hectare of USGs (which means a considerable saving of $92 \mathrm{~kg}$ of nitrogen). Optimum yield was achieved with $162 \mathrm{~kg}$ per hectare of prills versus $94 \mathrm{~kg}$ per hectare of USGs.

The extra production cost of USGs must remain below the potential fertilizer savings. However, placing the USGs at depth following transplantation does require more work. If this cannot be significantly reduced by introducing simple machines, in farms based on manual work, fertilizer savings may take precedence over labour savings. Furthermore, comparative tests carried out showed that placing a USG every $30 \mathrm{~cm}$ on every other line required 40 to 45 man-hours per hectare with an International Rice Research Institute applicator and 50 to 60 man-hours per hectare for manual applications.

Placing one or two USGs for every four clumps by hand represents a $25 \%$ increase in the work of transplantation. This increase is reasonable given the harvest gains and the relative importance of this stage compared with the others (tillage, puddling, levelling, fertilizing, weeding, harvesting and threshing).

\section{Conclusion}

Regardless of criterion considered (level of fertilizer or real/apparent utilization coefficients), the fertilizer form effect was greater than the dosage effect.

The increased percentages of fertilizer contribution may be due to limited nitrogen losses owing to: volatilization, nitrification-denitrification, immobilization or leaching (by rainwater). The significance of these factors varied according to soil type, form of fertilizer and placement.

Where prilled urea was applied to the surface, the formation of ammonium through hydrolysis was associated with major losses due to ammonia volatilization (Liu et al., 2015). The scale varied according to the concentration of ammonium, the $\mathrm{pH}$ of the floodwater, the balance of the carbonate-bicarbonate- $\mathrm{CO}_{2}$ system (which is controlled by biochemical activity - photosynthesis and respiration - of nearby organisms) and lastly by various environmental factors (light, temperature and wind). These are surface phenomena that can be reduced or eliminated by placing the treatments at depth. It should be pointed out that when prilled urea is added to the bottom of a water-filled furrow and covered up, the fertilizer moves and disseminates the ammonium up to the soil-water interface.

Similarly, the nitrification-denitrification processes can be reduced by placing the nitrogen at depth because there is less oxidation of the ammonium into nitrate in the narrow layer a few centimetres below ground surface. 
The low levels of nitrate at depth or ammonium at the surface would reduce the probable scale of losses due to leaching or entrainment. Another advantage to placing treatments at depth is that it does not inhibit the growth of blue-green algae and the associated symbiotic nitrogen fixation. The aforementioned advantages are even stronger when urea takes the form of USGs.

According to Savant and Stangel (1990), this must combine locally with a very strong ammonium concentration gradient in the soil-urea reaction zone. When growth begins, the plant's roots will avoid this area and, at a time when the plant's needs are low, the nitrogen will be stored in the soil's reserves. Subsequently, as the gradient decreases, the roots will spread into the reaction zone (Gaudin and Dupuy, 1999) and therefore benefit from the fertilizer's nitrogen for longer. This phenomenon is accentuated by a delayed input (Dupuy et al., 1990). This hypothesis is confirmed by the proper use of nitrogen fertilizer with grains that was not highlighted by experiments where USGs were added at the transplantation stage (Shiga et al., 1977).

Overall, there are three main factors behind the effectiveness of the USGs. The first is the deep placement, the second is the format of granules of at least 1 gram and the third is the delayed application. In order to position and maintain the fertilizer in the small area and create the right conditions for maintaining a strong ammonium gradient, it is essential to comply with the three above-mentioned conditions.

On a practical level, it is easy enough to produce USGs but applying them can be more problematic. Whether this is done manually or mechanically, the placement must be precise and remain undisturbed for at least a few weeks following the nitrogen application. This implies, inter alia, a good control over water. In fact, if application must take place around three weeks after the rice transplantation (tillering stage), then it should be borne in mind that rainfall is already high then and, except during droughts, paddy fields are completely flooded and difficult to drain. Therefore, optimal conditions for applying the USGs require the rice field to be dried out or at least the water levels to be reduced to 2 or $3 \mathrm{~cm}$. The movement of higher water levels would make the USGs rise, which would then yield the same results as for prilled urea. The magnitude of this phenomenon varies according to soil type. Sticky clay soils are better suited to the application of USGs than organic soils with a lumpy texture.

However, although USG treatments do very significantly improve the intervention rates of fertilizer, other limiting factors will affect both the utilization of fertilizer nitrogen and the stimulation effect of the plant's nitrogen uptake from the soil. The latter factor may be very significant, and mainly depends on the general nutritional condition of the plant. Particularly for low-phosphorus soils or soils with a high phosphorus fixing capacity (as in Madagascar), high levels of manure application will remain insufficient for ensuring that rice develops properly.

Lastly, there may be other relevant factors that are more difficult to assess (such as micronutrient deficiencies, permeability and so forth). While improving the efficiency of nitrogen fertilizer is a major part of rice production, it alone cannot solve all problems. 
In order to evaluate the impact of these various factors, additional studies around key indicators should be carried out. These might concern the analysis of rice roots and the kinetics of nitrogen uptake based on placement (form, date, depth and watering regime). Experiments using high nitrogen concentrations would monitor the performance of various forms of nitrogen in the soil and would determine any carryover effects.

\section{Acknowledgement}

This study was carried out in the framework of the FAO Fertilizer Program (called also Malagasy Fertilizer Program) and benefited from the financial support of CEA. It would not have been possible to complete the study without the technical assistance of the IAEA, and the authors would like to thank Dr Eskew for the valuable cooperation provided.

We should also like to thank the technical team of the Radioisotopes Laboratory of Antananarivo University, and all those who took part in implementing the tests.

\section{References}

Bandaogo, A., Bidjokazo, F., Youl, S., Safo, E., Abaidoo, R, \& Andrews, O. (2015). Effect of fertilizer deep placemnt with urea supergranule on nitrogen use efficiency of irrigated rice in Sourou valley (Burkina Faso). Nutrient Cycling in Agroecosystems, 102, 79-89.

https://doi.org/10.1007/s10705-014-9653-6

Chien, S.H., Prochnow, L.I., \& Cantarella, H. (2009). Recent developments of fertilizer production and use to improve nutrient efficiency and minimize environmental impacts. Advances in Agronomy, 102, 67-322. https://doi.org/10.1016/S0065-2113(09)01008-6

Dupuy, J., Gaudin, R., \& D’Onofrio, G. (1990). Etude à l'aide d'urée enrichie en ${ }^{15} \mathrm{~N}$ de la fertilisation azotée du riz inondé à Madagascar. III. Cinétique de prélèvement de l'azote apporté sous forme de supergranules d'urée ou de perlurée au repiquage du riz ou 21 jours après. L'Agronomie Tropicale, 45, 21-30.

Gaudin, R. \& Dupuy, J. (1999) Ammoniacal nutrition of transplanted rice fertilized with large urea granules. Agronomy Journal, 91, 33-36.

https://doi.org/10.2134/agronj1999.00021962009100010006x

Liu, T.Q., Fan, D.J., Zhang, X.X., Chen, J., Li, C.F., \& Cao, C.G. (2015). Deep placement of nitrogen fertilizers reduces ammonia volatilization and increases nitrogen utilization efficiency in no-tillage paddy fields in Central China. Field Crops Research, 184, 80-90.

https://doi.org/10.1016/j.fcr.2015.09.011

Savant, N.K., \& Stangel, P.J. (1990). Deep placement of urea supergranules in transplanted rice: principles and practices. Fertilizer Research, 25, 1-83.

https://doi.org/10.1007/BF01063765

Sharma, S.N., \& Prasad, R. (1980). Effect of rates of nitrogen and relative efficiency of sulphur coated urea and nitrapyrin-treated urea in dry matter production and nitrogen uptake by rice. Plant and Soil, 55, 389-396. https://doi.org/10.1007/BF02182699 


\section{Macrothink}

Journal of Agricultural Studies

ISSN 2166-0379 2018, Vol. 6, No. 1

Shiga, H., Ventura, W. B., \& Yoshida, T. (1977). Effect of deep placement of ball type fertilizer at different growth stages on yield and yield components of the rice plant in the Philippines. Plant and Soil, 47, 351-361. https://doi.org/10.1007/BF00011494

\section{Glossary for acronyms}

IAEA: International Atomic Energy Agency

CEA: French Alternative Energies and Atomic Energy Commission

FAO: Food and Agriculture Organization of the United Nations

\section{Copyright Disclaimer}

Copyright for this article is retained by the author(s), with first publication rights granted to the journal.

This is an open-access article distributed under the terms and conditions of the Creative Commons Attribution license (http://creativecommons.org/licenses/by/4.0/) 